\title{
Targeting B cell malignancies through human B cell receptor specific CD4 T cells
}

\author{
Jinsheng Weng", Flavio Egidio Baio, Kelsey Moriarty, Hiroki Torikai, Hua Wang, Zhiqiang Liu, Sourindra Maiti, \\ Dongho Gwak, Michael Popescu, Soung-chul Cha, Sattva S Neelapu, Larry Kwak
}

From 30th Annual Meeting and Associated Programs of the Society for Immunotherapy of Cancer (SITC 2015) National Harbor, MD, USA. 4-8 November 2015

\section{Background}

The $\mathrm{B}$ cell receptor (BCR) expressed by a clonal B cell tumor is a tumor specific antigen (idiotype). However, the $\mathrm{T}$ cell epitopes within human BCRs which stimulate protective immunity still lack detailed characterization.

\section{Methods}

In this study, we identified 17 potential CD4 $\mathrm{T}$ cell peptide epitopes derived from BCR heavy and light chain variable region sequences. Detailed analysis revealed these CD4 $\mathrm{T}$ cell epitopes stimulated Th1 CD4 T cells to directly recognize the autologous tumors by secretion of IFN- $\gamma$, indicating the epitopes are processed and presented by tumors.

\section{Results}

One BCR peptide-specific CD4 T cell line was also cytotoxic and lysed autologous tumor cells through the perforin pathway. Sequence analysis of the epitopes revealed 10 were potentially shared by multiple primary patients' tumors, and 16 had the capacity to bind more than one HLA DRB1 allele. T cells stimulated by shared epitopes recognized primary tumors expressing the same sequences on different HLA DRB1 alleles.

\section{Conclusions}

In conclusion, we identified multiple BCR-derived CD4 $\mathrm{T}$ cell epitopes with promiscuous HLA binding that are shared by up to $36 \%$ of patients, suggesting a strategy to overcome the requirement for individual preparation of therapeutic agents targeting idiotype.

The University of Texas MD Anderson Cancer Center, Houston, TX, USA

\section{Acknowledgements}

This study was support by the Leukemia and Lymphoma Society Specialized Center of Research Grant \#7262-08(LWK), Myeloma SPORE Grant

P50CA142509, Myeloma SPORE Career Program, the Brian D. Novis research grant from the International Myeloma Foundation, and the Lady Leukemia League Research Grant.

Published: 4 November 2015

doi:10.1186/2051-1426-3-S2-P59

Cite this article as: Weng et al:: Targeting B cell malignancies through human B cell receptor specific CD4 T cells. Journal for ImmunoTherapy of Cancer 2015 3(Suppl 2):P59.
Submit your next manuscript to BioMed Central and take full advantage of:

- Convenient online submission

- Thorough peer review

- No space constraints or color figure charges

- Immediate publication on acceptance

- Inclusion in PubMed, CAS, Scopus and Google Scholar

- Research which is freely available for redistribution 